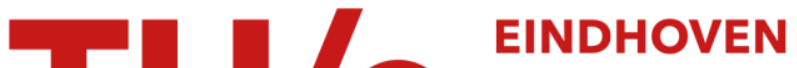 UNIVERSITY OF TECHNOLOGY
}

\section{Sealing method of dry etched AIAs/GaAs top mirrors in vertical cavity surface emitting lasers}

Citation for published version (APA):

Creusen, M. P., Bruyn, de, F., Karouta, F., Vleuten, van der, W. C., Roer, van de, T. G., Smalbrugge, E., \& Roy, van, B. H. (1999). Sealing method of dry etched AIAs/GaAs top mirrors in vertical cavity surface emitting lasers. Electrochemical and Solid-State Letters, 2(2), 83-85. https://doi.org/10.1149/1.1390742

DOI:

10.1149/1.1390742

Document status and date:

Published: 01/01/1999

Document Version:

Publisher's PDF, also known as Version of Record (includes final page, issue and volume numbers)

Please check the document version of this publication:

- A submitted manuscript is the version of the article upon submission and before peer-review. There can be important differences between the submitted version and the official published version of record. People interested in the research are advised to contact the author for the final version of the publication, or visit the $\mathrm{DOI}$ to the publisher's website.

- The final author version and the galley proof are versions of the publication after peer review.

- The final published version features the final layout of the paper including the volume, issue and page numbers.

Link to publication

\section{General rights}

Copyright and moral rights for the publications made accessible in the public portal are retained by the authors and/or other copyright owners and it is a condition of accessing publications that users recognise and abide by the legal requirements associated with these rights.

- Users may download and print one copy of any publication from the public portal for the purpose of private study or research.

- You may not further distribute the material or use it for any profit-making activity or commercial gain

- You may freely distribute the URL identifying the publication in the public portal.

If the publication is distributed under the terms of Article $25 \mathrm{fa}$ of the Dutch Copyright Act, indicated by the "Taverne" license above, please follow below link for the End User Agreement:

www.tue.nl/taverne

Take down policy

If you believe that this document breaches copyright please contact us at:

openaccess@tue.nl

providing details and we will investigate your claim. 


\title{
Sealing Method of Dry-Etched AlAs/GaAs Top Mirrors in Vertical Cavity Surface Emitting Lasers
}

\author{
M. Creusen, ${ }^{a, c}$ F. de Bruyn, ${ }^{b, d}$ F. Karouta, ${ }^{b, *}$, z W. C. van der Vleuten, ${ }^{a}$ T. G. van de Roer, ${ }^{b}$ \\ E. Smalbrugge, ${ }^{b}$ and B. H. van Roy ${ }^{b}$ \\ ${ }^{a}$ Department of Electrical Engineering and ${ }^{b}$ Department of Applied Physics, Eindhoven University of Technology, COBRA Inter- \\ University Research Institute on Communication Technology, Group of Electronic Devices, Eindhoven, The Netherlands
}

\begin{abstract}
A versatile sealing process for AlAs layers is presented. This sealing prevents the AlAs layers of AlAs/GaAs top distributed Bragg reflectors from further undesired oxidation during the wet oxidation of the AlAs current constriction layers in vertical cavity surface emitting lasers. This method has been successfully applied to protect the etched pillars in top mirrors although those pillars were plasma dry etched.

(C) 1999 The Electrochemical Society. S1099-0062(98)07-019-9. All rights reserved.
\end{abstract}

Manuscript submitted July 10, 1998; revised manuscript received September 15, 1998. Available electronically November 18, 1998.

The selective wet oxidation of Al-rich layers like AlAs and $\mathrm{AlGaAs}$ and their use in the fabrication of optoelectronic devices such as vertical cavity surface emitting lasers (VCSELs) has become an important issue in the last few years. Numerous authors ${ }^{1,2}$ are using this process to oxidize AlAs layers within the cavity to obtain a desired current constriction. This is absolutely fundamental in VCSELs when low voltage devices are required such as can be realized using the so-called intracavity contacted VCSELs. These devices have lower serial resistance as the current does not flow through the AlAs/GaAs distributed Bragg reflectors (DBR).

The wet oxidation of AlAs and Al-rich AlGaAs layers is usually performed at a temperature of $400-500^{\circ} \mathrm{C}$ in a nitrogen ambient saturated with water vapor. In this process, two AlAs layers within the laser cavity are wet oxidized, leaving a small window in the middle of the device which allows the current to flow in the same area where the photons are generated. This oxidation achieves simultaneously lateral photon and current confinement. This technique has some drawbacks. The first one is the stress induced in the structure at the oxide-semiconductor interface which can lead to device degradation. The second is related to the processing of the VCSELs: the already exposed AlAs layers of the top AlAs/GaAs DBR must be protected from undesired oxidation. One way of circumventing this problem is to use $\mathrm{Al}_{0.96} \mathrm{Ga}_{0.04} \mathrm{As} / \mathrm{GaAs} \mathrm{DBR}$ instead of $\mathrm{AlAs} / \mathrm{GaAs}$ because the oxidation rate of $\mathrm{Al}_{0.96} \mathrm{Ga}_{0.04} \mathrm{As}$ is much lower than that of AlAs. This would introduce another problem as a larger number of pairs are necessary to achieve the required reflectance. The second way is to seal the top DBR mirror and thus protect the AlAs layers from further oxidation during the oxidation of the current constriction layers.

Huffaker et al. ${ }^{3}$ were the first to publish about sealing AlAs layers using a method consisting of a rapid thermal anneal (RTA) step at $\sim 500$ to $600^{\circ} \mathrm{C}$ in forming gas $\left(90 \% \mathrm{~N}_{2}, 10 \% \mathrm{H}_{2}\right)$ after having exposed the AlAs to room temperature. The annealing is thought to form a thin surface barrier layer preventing further wet oxidation. Lim et al. ${ }^{4}$ reported also about a sealing method using the principle that the wet oxidation is a one-shot process. This means that the oxidation does not continue after it has been interrupted. They found that a wet oxidation at $408^{\circ} \mathrm{C}$ for $15 \mathrm{~s}$ completely sealed the DBRs. Both papers dealt with wet-etched mesas. In our case, where the top mirror mesa was dry etched, these methods did not work. Dry etching of the top DBR mesas is widely used as it presents advantages over wet etching such as better uniformity and no underetch profile. In this paper an efficient sealing method of AlAs layers is reported which is applicable also to dry-etched DBRs.

The VCSEL structure used is a molecular beam epitaxy-grown structure having 18 pairs of AlAs/GaAs top DBRs, a $6 \times \lambda$ cavity with a top GaAs p-layer and a bottom GaAs n-layer destined for the

\footnotetext{
* Electrochemical Society Active Member.

c Present address: IMEC, Leuven, Belgium.

d Present address: Ericsson, The Netherlands.

z E-mail: f.karouta@tue.nl
}

intracavity contacts. Finally, 28 pairs of AlAs/GaAs form the bottom DBR mirror. The active layer is formed by $2 \times 8 \mathrm{~nm}$ thick quantum wells of $\mathrm{In}_{0.17} \mathrm{Ga}_{0.83}$ As surrounded by two AlAs layers intended to be oxidized in order to ensure the electrical and optical confinements. The VCSEL processing is schematized in Fig. 1. The results of those VCSELs have been reported earlier. ${ }^{5,6}$

The first attempt at sealing consisted of depositing a $0.9 \mu \mathrm{m}$ thick $\mathrm{SiN}_{x}$ layer around the top DBR after the mesa was etched. This offered sufficient protection for large devices. However, the DBRs of $5 \mu \mathrm{m}$ devices and smaller were oxidized. ${ }^{5}$ Then, the method of Huffaker et al. $^{3}$ was tried. This technique failed when applied to DBRs etched using reactive ion etching (RIE) based on $\mathrm{SiCl}_{4}-\mathrm{Ar}$ chemistry. Even so, based on this method, we introduced a number of variations, e.g., extending the exposure time to ambient of the

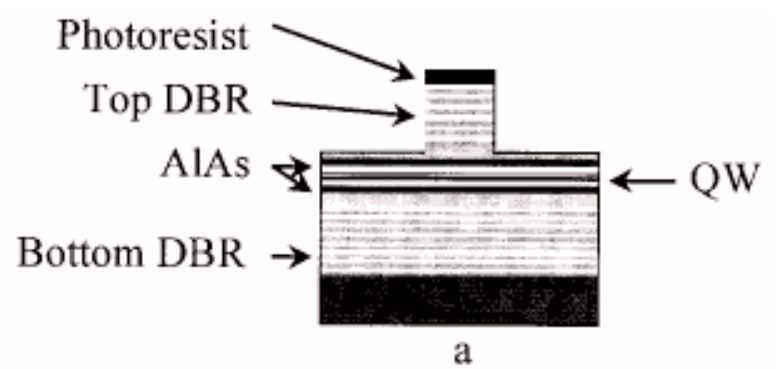

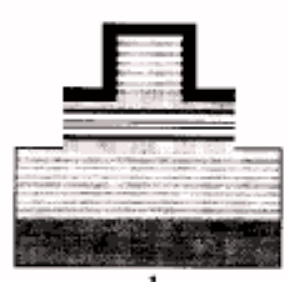

b

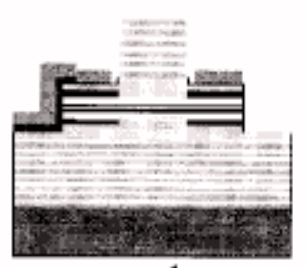

d

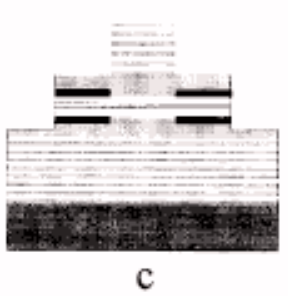

C

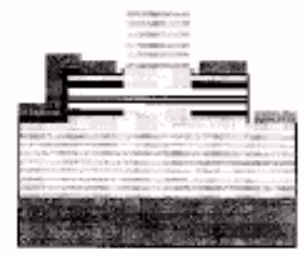

$\mathrm{e}$
Figure 1. Processing steps of intracavity VCSELs: (a) first RIE-etched mesa, (b) second RIE-etched mesa, (c) wet oxidation of the AlAs constriction layers in the laser cavity, (d) p-contact on laser cavity top isolated with a $\mathrm{SiN}_{x}$ layer from the $\mathrm{n}$-contact layer, and (e) the n-contact on the n-contact layer near the bottom DBR. 
Table I. An overview of the sealing results of dry etched mesas after introducing the wet dip etching demonstrating its efficiency.

\begin{tabular}{lcccc} 
Run & $\begin{array}{c}\text { Wet/dry } \\
\text { etched DBRs }\end{array}$ & $\begin{array}{c}\text { Dip etch } \\
\text { in RTA }\end{array}$ & Gases & Sealed \\
\hline 25 & Dry & Yes & $\mathrm{O}_{2} / \mathrm{N}_{2}$ & Yes \\
26 & Dry & Yes & $\mathrm{H}_{2} / \mathrm{N}_{2}$ & Yes \\
27 & Dry & Yes & $\mathrm{O}_{2} / \mathrm{N}_{2}$ & Yes \\
28 & Dry & Yes & $\mathrm{H}_{2} / \mathrm{N}_{2}$ & Yes \\
29 & Dry & No & $\mathrm{H}_{2} / \mathrm{N}_{2}$ & No \\
30 & Dry & Yes & $\mathrm{O}_{2} / \mathrm{N}_{2}$ & Yes \\
31 & Dry & Yes & $\mathrm{H}_{2} \mathrm{~N}_{2}$ & Yes
\end{tabular}

etched DBRs up to $24 \mathrm{~h}$ and using a mixture of $\mathrm{O}_{2} / \mathrm{N}_{2}$ (1:9 volume) instead of the forming gas during the $30 \mathrm{~s}$ RTA step at $550^{\circ} \mathrm{C}$.

Also, several combinations of those variations were tried and it has been found that most of the samples where the DBRs are etched chemically are effectively sealed provided they are annealed for at least $30 \mathrm{~s}$ at $550^{\circ} \mathrm{C}$ either in $\mathrm{H}_{2} / \mathrm{N}_{2}$ or in the $\mathrm{O}_{2} / \mathrm{N}_{2}$ mixture. The step of exposing the etched DBRs to air ambient for $24 \mathrm{~h}$ seems to be redundant. On the other hand, all dry-etched samples were unsealed irrespective of the combination used.

Considering the fact that the wet oxidation would be a one-shot process $^{4}$ the possibility of sealing the DBRs by means of a short wet oxidation of the exposed AlAs layers was investigated. We call this procedure a preoxidation step. This is intended to create a shallow oxide surface on the walls of the AlAs layers which is able to prevent the DBRs from further oxidation during the intentional selective oxidation of the AlAs constriction layers. The samples are exposed to an $\mathrm{H}_{2} \mathrm{O}$ vapor $\left(95^{\circ} \mathrm{C}\right)$ which is carried by nitrogen $(0.6$ $\mathrm{L} / \mathrm{min}$ ) at $400^{\circ} \mathrm{C}$ for $30-120 \mathrm{~s}$. The result was that some of the dryetched DBRs were sealed and others were not.

An important difference between the dry-etched mesas and the wet-etched ones is that in the dry process the etched walls are exposed to the plasma which introduces some damage to the sidewalls of the mesa. We believe that during the preoxidation step, these contaminated sidewalls do not oxidize completely, or, at least not uniformly, which makes the subsequent sealing process nonreproducible. A simple way to get rid of plasma induced damage or contamination is to apply a short wet-etch dip directly after the dry-etch step of the DBRs. The sample is dip etched in an $\mathrm{NH}_{4} \mathrm{OH}: \mathrm{H}_{2} \mathrm{O}_{2}: \mathrm{H}_{2} \mathrm{O}$ (1:2:50) solution for $10 \mathrm{~s}$ at room temperature. ${ }^{7}$ This solution etches the sidewalls of the DBR and affects the shape of the mesa. This leads to slightly nonvertical sidewalls but in the same time it removes the plasma induced damage producing surfaces comparable to those of fully wet-etched DBRs. Subsequently, the sealing process has been continued without performing the preoxidation step. The samples were only annealed in forming gas or in the $\mathrm{O}_{2} / \mathrm{N}_{2}$ mixture at $550^{\circ} \mathrm{C}$ for $30 \mathrm{~s}$. No special precaution was taken to avoid a de facto exposure to air during the few minutes when the sample was transported either to perform the dip etch or the annealing step. All runs have resulted in fully sealed top DBR mirrors. The wet-etch dip appears to be a key step in sealing the top DBR mirrors of the VCSELs. Table I shows an overview of the runs using the wet-etch dip step.

Figure 2 shows a cross section scanning electron micrograph (SEM) of the sealed DBR of a run where the dip etch is combined with the annealing step in the $\mathrm{O}_{2} / \mathrm{N}_{2}$ mixture. Figure 3 shows a cross-sectional SEM photograph of a run where the top DBR mesa was dry etched followed by the sealing process before a second mesa through the bottom DBR was also dry etched. Afterward the sample was wet oxidized; it was clearly observed that the lower unsealed DBR was oxidized while the upper DBR was unaffected.

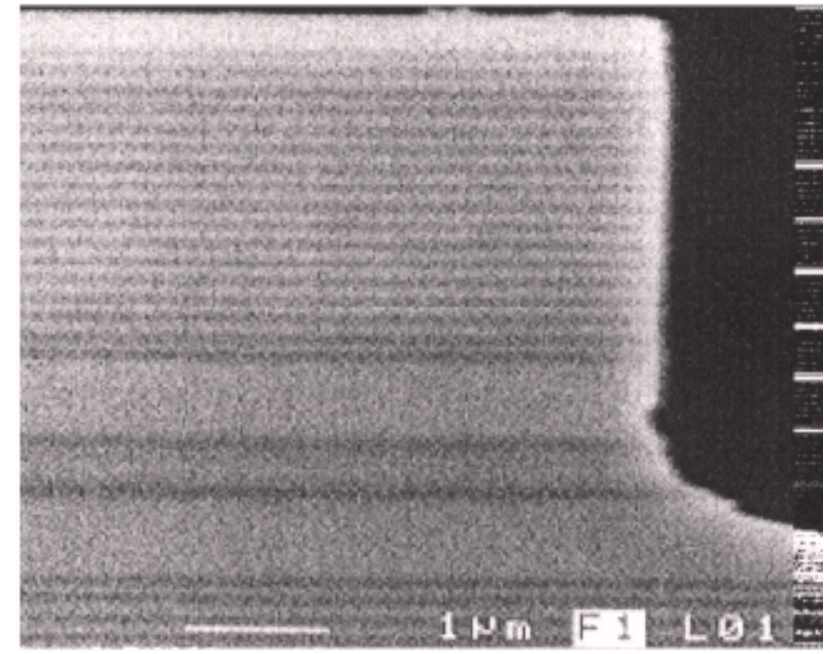

Figure 2. Cross-sectional photograph of a run where the top DBR has gotten a wet-etch dip followed by annealing in $\mathrm{O}_{2} / \mathrm{N}_{2}$ before wet oxidation. The AlAs layers (dark gray) remain unoxidized.

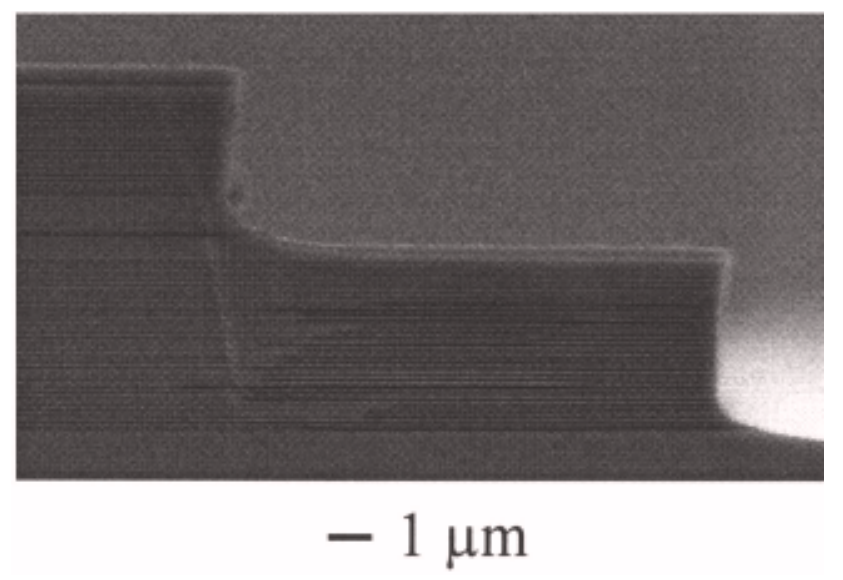

Figure 3. Sealed top DBR mirror and oxidized bottom DBR mirror of a run where the top DBR is sealed and the bottom one is not. The dark gray AlAs layers become completely black when oxidized.

Although there is no clear explanation of the mechanism of the sealing, and in order to clarify this point we developed the following theory based on the above mentioned results. The dry etching of the top DBR is performed using $\mathrm{SiCl}_{4}$ and $\mathrm{Ar}$ and it results in vertical sidewalls which are damaged or contaminated by the plasma but they are still carbon free. The exposed AlAs layers of this DBR get oxidized due to hydrolysis ${ }^{8-10}$ and become an amorphous combination of $\mathrm{Al}_{2} \mathrm{O}_{3}, \mathrm{AlO}(\mathrm{OH})$, and $\mathrm{Al}(\mathrm{OH})_{3}$. However, this oxide is not uniform, or it contains some microstructures as a direct result of plasma damage. Therefore, this oxide cannot be used to seal the top DBR. The dip wet etching removes the contaminated parts and helps in getting a uniform and smooth surface on the edge of the AlAs layer. The annealing step leads to an As diffusion from the AlAs layer into the oxide. ${ }^{11}$ Arsenic reacts with $\mathrm{AlO}(\mathrm{OH})$ and $\mathrm{Al}(\mathrm{OH})_{3}$ producing the more stable $\mathrm{Al}_{2} \mathrm{O}_{3}$ with removal of $\mathrm{H}_{2}$ and $\mathrm{AsH}_{3} .{ }^{11}$ Subsequently, the oxide is transformed into a polycrystalline $\mathrm{Al}_{2} \mathrm{O}_{3}$ which protects the inner part of the AlAs from further oxidation and, hence, seals the AlAs layers of the DBR mirror.

In summary, we have demonstrated a sealing process for AlAs layers used in dry-etched DBR mirrors of VCSELs that protects them efficiently against wet oxidation. To our knowledge, this is the first time that such a technique is described where dry-etched AlAs layers used in top DBR mirrors are sealed. A short wet-etch dip following the dry etch process is the key to success of this sealing process. 
We thank G. Acket, and L. Kaufmann for fruitful discussions. This work was supported by the Dutch Ministry of Economic Affairs through the Innovative Research Program Electro-Optics.

Eindhoven University assisted in meeting the publication costs of this article.

\section{References}

1. D. G. Deppe, D. L. Huffaker, T-H. Oh, H. Deng, and Q. Deng, IEEE J. Quantum Electron., 3, 893 (1997)

2. W. W. Chow, K. D. Choquette, M. H. Crawford, K. L. Lear, and G. R. Hadley, IEEE J. Quantum Electron., 33, 1810 (1997).

3. D. L. Huffaker, D. G. Deppe, C. Lei, and L. A. Hodge, Appl. Phys. Lett., 68, 1948 (1996).

4. D. H. Lim, G. M. Yang, J. H. Kim, K. Y. Lim, and H. J. Lee, Appl. Phys. Lett., 71, 1915 (1997).
5. M. Creusen, M.S. Thesis, Eindhoven University of Technology, Eindhoven, The Netherlands (1996).

6. T. G. van de Roer, M. Creusen, E. Smalbrugge, F. de Bruyn, W. C. van der Vleuten, and F. Karouta, in MOC/GRIN 97, p.96, Waseda University, Tokyo, Japan, Oct 7-9, 1997.

7. F. de Bruyn, MS Thesis, M.S. Thesis, Eindhoven University of Technology, Eindhoven, The Netherlands (1997).

8. J. M. Dallesasse, N. El-Zein, N. Holonyak, Jr., K. C. Hsieh, R. D. Burnham, and R. D. Dupuis, J. Appl. Phys., 68, 2235 (1990).

9. J. M. Dallesasse, N. Holonyak, Jr., A. R. Sugg, T. A. Richard, and N. El-Zein, Appl. Phys. Lett., 57, 2844 (1990).

10. A. R. Sugg, N. Holonyak, Jr., J. E. Baker, F. A. Kish, and J. M. Dallesasse, Appl. Phys. Lett., 58, 1199 (1991)

11. A. R. Sugg, E. I. Chen, N. Holonyak, Jr., K. C. Hsieh, J. E. Baker, and N. Finnegan, J. Appl. Phys., 74, 3880 (1993). 